\title{
Dynamic Economic Dispatch Mempertimbangkan Prohibited Operating Zones Menggunakan Algoritma Improved Artificial Bee Colony
}

\author{
Giorgio Rendra Gumelar, Rony Seto Wibowo, Adi Soeprijanto \\ Departemen Teknik Elektro, Fakultas Teknologi Elektro, Institut Teknologi Sepuluh Nopember (ITS) \\ E-mail: giorgiorendra21@gmail.com
}

\begin{abstract}
Abstrak-Dynamic Economic Dispatch (DED) adalah solusi untuk menekan biaya produksi pembangkitan listrik dan efisiensi biaya bahan bakar dengan melakukan optimisasi biaya pembangkitan pada unit pembangkit. Perubahan permintaan beban tiap waktunya mengakibatkan berubahnya biaya pembangkitan per satuan waktu. Fungsi Dynamic Economic Dispatch (DED) untuk mendapatkan pembangkitan daya yang optimal dengan biaya seekonomis mungkin sambil tetap melayani kebutuhan daya ke konsumen selama 24 jam. Beberapa karakteristik dan batasan operasi yang terdapat pada Dynamic Economic Dispatch antara lain kerugian transmisi, batasan ramp rate, permintaan beban dinamis, Prohibited Operating Zones, dan spinning reserve. Pada studi ini menunjukkan implementasi algoritma Improved Artificial Bee Colony (IABC) pada perhitungan Dynamic Economic Dispatch. Beberapa batasan operasi yang dipertimbangkan dalam perhitungan studi antara lain, Prohibited Operating Zones dan batasan operasi ramp rate. Pengujian simulasi Dynamic Economic Dispatch dilakukan dengan menggunakan sistem 6 unit generator dan sistem 15 unit generator. Hasil simulasi menunjukkan batasan ramp rate dan Prohibited Operating Zones berdampak pada biaya pembangkitan. Pada sistem 6 unit generator dengan mempertimbangkan Prohibited Operating zones menggunakan algoritma Improved Artificial Bee Colony (IABC) total biaya pembangkitan sebesar \$ $313404 / h$ atau lebih murah $1.002 \%$ dibandingkan dengan metode Improved Bee Algorithm (IBA).
\end{abstract}

Kata Kunci-Dynamic economic dispatch, prohibited operating zones, improved artificial bee colony.

\section{PENDAHULUAN}

B IAYA pengoperasian pembangkitan berbeda-beda antara unit pembangkit satu dengan unit pembangkit lainnya. Maka, salah satu solusi permasalahan untuk menekan biaya produksi pembangkitan listrik adalah dengan melakukan Economic Dispatch (ED). Economic Dispatch (ED) bertujuan menentukan besar daya keluaran yang harus dibangkitkan pada masing-masing pembangkit dengan biaya operasional terendah untuk memenuhi permintaan beban. Economic Dispatch (ED) dapat mengatur penjadwalan unit pembangkit pada keadaan statis (satu jam) saja, menyebabkan Economic Dispatch (ED) tidak berlaku untuk beban yang dinamis. Dynamic Economic Dispatch (DED) merupakan pengembangan dari Economic Dispatch (ED) dengan memperhatikan batasan ramp rate pada tiap-tiap unit pembangkitnya. Fungsi Dynamic Economic Dispatch (DED) adalah menentukan penjadwalan pembangkitan daya untuk masing-masing unit pembangkit secara ekonomis dalam interval waktu dispatch 24 jam [1][2]. Praktiknya, unit pembangkit termal atau hidro memungkinkan terdapat zona batasan operasi atau disebut juga dengan Prohibited Operating Zones (POZ). Prohibited Operating Zones (POZ) adalah zona yang membatasi kerja unit pembangkit yang muncul disebabkan adanya batasan fisik pada komponen unit pembangkit itu sendiri. Pada daya output tertentu, getaran dapat muncul pada peralatan. Jika frekuensi pada getaran sama dengan frekuensi natural menyebabkan terjadinya resonansi pada peralatan yang dapat merusak peralatan listrik.

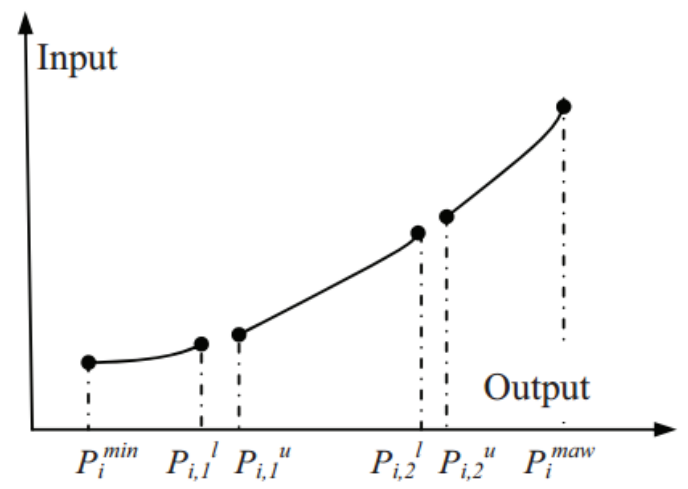

Gambar 1. Fuel Cost Function dengan POZ

Prohibited Operating Zones (POZ) menghasilkan kurva cost function yang non-convex dan memiliki disjoint region [3]. Untuk mengatasi permasalahan Prohibited Operating Zones (POZ) digunakan pendekatan algoritma metaheuristik swarm intelligence yaitu algoritma Improved Artificial Bee Colony (IABC). Metode yang ditujukan akan diujicoba dengan sistem IEEE 6 unit generator dan sistem IEEE 15 unit generator. Pengujian tanpa mempertimbangkan kerugian transmisi.

\section{DYNAMIC ECONOMIC DISPATCH MEMPERTIMBANGKAN PROHIBITED OPERATING ZONES}

Dynamic economic dispatch (DED) adalah economic dispatch yang memiliki kemampuan prediktif beban untuk satu periode tertentu dengan mengkoordinasikan prediksi perubahan beban dengan kemampuan laju respon dari unit pembangkit. Tujuan dari DED adalah untuk menentukan luaran daya optimal dari unit-unit pembangkit listrik terhubung yang memenuhi kebutuhan beban permintaan 
dengan memenuhi beberapa kendala operasi untuk 24 jam penyaluran daya [1]. Pembahasan mengenai fungsi objektif dan konstrain DED adalah sebagai berikut:

Fungsi objektif pada permasalahan DED adalah untuk meminimalkan total biaya bahan bakar dari unit pembangkitan tenaga listrik [4] dan ditunjukkan pada persamaan (1).

$$
F_{T}=\sum_{t=1}^{N} f_{i}\left(P_{i}^{t}\right)=\sum_{t=1}^{N} a_{i}\left(P_{i}^{t}\right)^{2}+b_{i} P_{i}^{t}+c_{i}
$$

Dimana $f_{\mathrm{i}}\left(P_{\mathrm{i}}\right)$ adalah fungsi biaya dari generator ke-i dan $P^{\mathrm{t}_{\mathrm{i}}}$ adalah luaran daya dari generator ke-i pada waktu $\mathrm{t}, \forall i \in$ $\{1,2,3, \ldots, N\}$ dan $\forall t \in\{1,2,3, \ldots, T\}$. Total daya aktif ditunjukkan pada persamaan (2).

$$
\sum_{n=1}^{N} P_{n}-P_{D}-P_{\text {Loss }}=0
$$

Dimana $P_{n}$ adalah daya pembangkitan dari generator ke-i, $P_{D}$ adalah daya yang diminta beban, dan $P_{\text {loss }}$ adalah kerugian daya transmisi. Ploss didapatkan melalui $B$ coefficient.

$$
P_{L}^{t}=\sum_{i=1}^{N} \sum_{j=1}^{N} P_{i}^{t} B_{i j} P_{j}^{t}+\sum_{i=1}^{N} B_{0 i} P_{i}^{t}+B_{00}
$$

Daya keluaran tiap pembangkit harus berada dibawah daya maksimum yang diperbolehkan dan di atas daya minimum yang diperbolehkan pada tiap unit. Keluaran daya dari generator idealnya bekerja di dalam batasan tersebut.

$$
P_{n} \min \leq P_{n} \leq P_{n} \max
$$

Batasan ramp-rate digunakan untuk mencegah efek yang tidak diinginkan akibat perubahan dinamis yang cepat dan melebihi kemampuan generator. Sesuai dengan karakteristik batasan ramp rate pada pembangkit pada persamaan (5).

$$
\begin{aligned}
& U R_{i} \geq P_{i}^{t}-P_{i}^{t-1} \\
& D R_{i} \geq P_{i}^{t-1}-P_{i}^{t}
\end{aligned}
$$

Dimana $P_{i}^{t-1}$ adalah daya yang dibangkitkan pada periode sebelumnya, DR dan UR menunjukkan nilai laju turun dan nilai laju naik. Bila nilai ramp rate diterapkan pada operasi unit pembangkit, maka persamaan (5) berubah menjadi,

$$
\max \left(P_{i}^{\min }, P_{i}^{t-1}-D R_{i}\right) \leq P_{i} \leq \min \left(P_{i}^{\max }, P_{i}^{t-1}-U R_{i}\right)
$$

Dalam praktek nyata, nilai profil kurva karakteristik input-output di sekitar POZ didasarkan pada catatan operasi atau kinerja aktual unit pembangkit. Penjelasan tentang POZ pada unit pembangkit ditunjukkan pada persamaan (7).

$$
\begin{gathered}
P_{i}^{t}=\left\{\begin{array}{c}
P_{i, \min } \leq P_{i}^{t} \leq P_{i, 1}^{l} \\
P_{i, j-1}^{u} \leq P_{i}^{t} \leq P_{i, j}^{l} \\
P_{i, n i}^{u} \leq P_{i}^{t} \leq P_{i, \max }
\end{array}\right. \\
j=2,3, \ldots, n_{i}, t=1,2, \ldots, T
\end{gathered}
$$

Dimana $n_{i}$ adalah jumlah POZ dari generator. $P l_{i, j}$ dan $P u_{i, j}$ adalah batas bawah dan batas atas dari daya output POZ. Gambar kurva POZ seperti ditunjukkan pada gambar 1 .

\section{IMPROVED ARTIFICIAL BEE COLONY}

\section{A. Artificial Bee Colony}

Dalam kehidupan nyata, beberapa tugas koloni lebah dilakukan oleh individu-individu khusus. Lebah khusus ini mencoba memaksimalkan jumlah nektar yang tersimpan di sarang dengan menggunakan pembagian kerja dan pengorganisasian yang efisien. Algoritma Artificial Bee Colony (ABC), adalah algoritma optimasi yang mensimulasikan perilaku kawanan lebah dalam mencari sumber-sumber makan [5]. Pemodelan algoritma ABC digambarkan terdiri dari tiga jenis lebah: lebah pekerja (employed bees), lebah penonton (onlooker bees), dan lebah pengintai (scout bee).

Separuh dari koloni tersebut terdiri dari lebah pekerja, dan separuh lainnya termasuk lebah penonton. Lebah pekerja bertugas mengeksploitasi sumber nektar yang telah dieksplorasi sebelumnya dan memberikan informasi kepada lebah penonton tentang kualitas sumber makanan yang mereka eksploitasi. Lebah penonton yang menunggu di sarang memutuskan sumber makanan mana yang akan dieksploitasi selanjutnya berdasarkan informasi yang diberikan oleh lebah pekerja. Lebah pengintai akan secara acak mencari lingkungan baru untuk menemukan sumber makanan baru tergantung pada motivasi internal atau berdasarkan kemungkinan petunjuk dari luar .

Perilaku lebah dalam mencari sumber makanan ini diimplementasikan ke dalam algoritma Artificial Bee Colony dapat dijabarkan sebagai berikut:

1. Pada tahap inisialisasi awal, para lebah mulai mengeksplorasi lingkungan secara acak untuk mencari sumber makanan.

2. Setelah menemukan sumber makanan, lebah menjadi pekerja dan mulai mengeksploitasi sumber makanan yang telah ditemukan. Lebah pekerja kembali ke sarang membawa nektar dan membongkar nektar. Setelah membongkar nektar, lebah pekerja dapat kembali ke situs sumber makanan atau dapat berbagi informasi tentang situs sumber makanannya dengan melakukan tarian (waggle dance) di area tarian. Jika sumber makanan habis, lebah pekerja akan menjadi lebah pengintai dan mulai mencari sumber baru secara acak.

3. Lebah penonton menunggu di sarang dan menonton tarian petunjuk lokasi sumber-sumber makanan yang menguntungkan dan memilih situs sumber makanan tergantung pada frekuensi tarian yang sebanding dengan kualitas sumbernya [6][7][8].

Dalam algoritma ABC yang diusulkan oleh Karaboga, posisi sumber makanan merupakan solusi optimasi dan jumlah nektar sumber makanan merupakan profitabilitas (kebugaran) dari solusi yang terkait. Setiap sumber makanan dieksploitasi hanya oleh satu lebah pekerja. Dengan kata lain, jumlah lebah pekerja sama dengan jumlah sumber makanan yang ada. Lebah pekerja yang sumber makanannya telah habis akan menjadi lebah pengintai [8].

Dengan menggunakan analogi kecerdasan yang muncul dalam mencari makan lebah dan algoritma $\mathrm{ABC}$, unit-unit algoritma $\mathrm{ABC}$ dasar dapat dijelaskan sebagai berikut:

1. Produksi Sumber Makanan Awal Implementasi algoritma dimulai dengan menentukan sumber makanan secara acak yang 
sesuai dengan solusi di ruang pencarian. Sumber makanan awal diproduksi secara acak dalam batasan-batasan parameter yang telah ditentukan.

$X_{i j}=X_{j \min }+\operatorname{rand}(0,1)\left(X_{j \max }-X_{j \min }\right)$

Dimana $i=1 . . . S N, j=1 \ldots . D . S N$ adalah jumlah sumber makanan dan $\mathrm{D}$ adalah jumlah parameter yang akan dioptimasi.

Setelah proses inisialisasi, populasi sumber makanan (solusi) dikenai siklus pengulangan pada fase lebah pekerja, lebah penonton dan lebah pengintai. Kriteria penghentian siklus pengulangan algoritma $\mathrm{ABC}$ akan terjadi saat siklus pengulangan mencapai jumlah siklus maksimum.

2. Pengiriman Lebah Pekerja ke Lokasi Sumber Makanan

Masing-masing lebah pekerja dipasangkan hanya dengan satu sumber makanan. Oleh karena itu, jumlah situs sumber makanan sama dengan jumlah lebah yang pekerja. Lebah pekerja menghasilkan nilai modifikasi posisi sumber makanan dalam ingatannya tergantung pada informasi lokal (informasi visual) dan menemukan sumber makanan tetangga, dan kemudian mengevaluasi kualitasnya. Di ABC, sumber makanan tetangga didefinisikan pada persamaan (9)

$$
V_{i j}=X_{i j}+\theta_{i j}\left(X_{i j}-X_{k j}\right)
$$

Dimana $V_{i j}$ adalah posisi baru dari sumber makanan ke-I untuk komponen ke-J, sedangkan $X_{i j}$ adalah posisi lama dari sumber makanan ke-I untuk komponen ke-J. I $=1,2, \ldots, \mathrm{SN} ; \mathrm{J}=1,2, \ldots, \mathrm{n} ; \mathrm{k}=$ $1,2, \ldots, \mathrm{SN}$. Dimana SN adalah jumlah dari lebah pekerja.

Setelah mendapatkan nilai $V_{i}$ yang memuaskan, nilai fitness untuk solusi $V_{i}$ didapatkan dengan perhitungan persamaan (10).

$$
\text { fitness }_{i}=\left\{\begin{array}{cc}
1 /\left(1+f_{i}\right), & f_{i} \geq 0 \\
1+a b s\left(f_{i}\right), & f_{i}<0
\end{array}\right.
$$

Dimana fi adalah nilai biaya dari solusi $V_{i}$. Nilai yang lebih baik dipilih tergantung pada nilai fitness yang mewakili jumlah nektar sumber makanan di $X_{i}$ dan $V_{i}$. Jika sumber makananvi lebih tinggi daripada $X_{i}$, lebah pekerja akan mengingat posisi baru dan melupakan yang lama. Jika tidak posisi sebelumnya disimpan di memori.

3. Perhitungan nilai probabilitas yang meliputi seleksi probabilitas

Setelah semua lebah bekerja menyelesaikan pencarian mereka, mereka berbagi informasi yang berkaitan dengan jumlah nektar dan posisi sumber makanan dengan lebah penonton di area tarian. Lebah penonton mengamati informasi nektar yang diambil dari semua lebah pekerja dan memilih lokasi sumber makanan dengan probabilitas yang tinggi. Seleksi probabilitas ini bergantung pada solusi nilai fitness pada populasi tersebut. Nilai fitness didapatkan melalui persamaan (11).

$$
P_{i}=\frac{\text { fitness }_{i}}{\sum_{i=1}^{S N} \text { fitness }_{i}}
$$

Dalam skema seleksi probabilistik ini, karena jumlah nektar sumber makanan (fitness of solution) meningkat, jumlah penonton yang berkunjung meningkat juga.

4. Pemilihan sumber makanan oleh lebah penonton Masing-masing sumber makanan dihasilkan dari bilangan acak dengan kisaran $[0,1]$. Jika nilai probabilitas lebih besar dari angka acak ini maka lebah penonton menghasilkan modifikasi pada posisi lokasi sumber makanan ini dengan menggunakan Persamaan (9) Setelah sumber dievaluasi, pemilihan acak diterapkan dan lebah penonton menghafal posisi baru dengan melupakan yang lama atau menyimpan yang lama. Proses ini berulang sampai semua lebah penonton didistribusikan ke situs sumber makanan.

5. Kriteria Limit dan Lebah Pengintai

Setelah semua lebah pekerja dan lebah penonton menyelesaikan pencarian mereka, algoritma tersebut memeriksa apakah ada sumber yang telah dieksploitasi habis. Untuk memutuskan apakah sebuah sumber harus ditinggalkan dapat digunakan counter yang akan selalu diperbarui selama pencarian. Jika nilai counter lebih besar dari parameter kontrol algoritma ABC (limit), maka sumber dapat diasumsikan sudah habis dan dapat ditinggalkan.

Dalam ABC, diasumsikan bahwa hanya satu sumber yang bisa habis dalam setiap siklus, dan hanya satu lebah yang dapat digunakan menjadi lebah pengintai.

\section{B. Improved Artificial Bee Colony}

Improved Artificial Bee Colony merupakan pengembangan dari Artificial Bee Colony. Pada improved artificial bee colony, selain menggunakan parameter kontrol pada artificial bee colony, terdapat parameter tambahan yaitu, Modification Rate (MR) dan Scaling Factor (SF) dimana dua parameter ini yang akan mengontrol frekuensi pertubasi dan magnitude pertubasi [7][9]. Berdasarkan hal tersebut kita dapat memodifikasi nilai update sumber makanan pada persamaan (12) menjadi

$$
v_{i j}=\left\{\begin{aligned}
x_{a j}+S F\left(x_{i j}-x_{b j}\right), & R_{i j}<M R \\
x_{i j}, & \text { lainnya }
\end{aligned}\right.
$$

\section{Simulasi IABC Pada Permasalahan Dynamic Economic Dispatch Mempertimbangkan POZ}

Prosedur aplikasi IABC adalah sebagai berikut :

1. Inisialisasi input program dan data sistem yang akan dioptimasi. Input program berupa besar koloni, jumlah sumber makanan, limit, nilai modification rate, scaling factor dan maksimal iterasi yang akan dijalankan. Sedangkan data sistem adalah data unit generator, nilai cost function, POZ, dan total beban yang diminta. 
2. Penentuan calon-calon kandidat makanan yang akan dibandingkan para lebah, makanan adalah representasi dari daya output generator yang nantinya akan dioptimasi.

3. Pengecekan calon makanan satu persatu dan akan diambil informasinya oleh lebah-lebah. Nantinya lebah akan menentukan apakah sumber makanan tersebut perlu di update lokasinya atau tidak dan akan diperiksa kondisinya, melanggar batasan yang ada atau tidak.

4. Setelah itu setiap kandidat makanan akan dihitung biaya pembangkitannya dan akan dihitung nilai fitness dari masing- masing kandidat yang ada. Kandidat makanan dengan biaya termurah akan disimpan untuk sementara waktu yang nantinya akan dibandingkan dengan calon kandidat terbaik dari iterasi selanjutnya.

5. Proses ini akan berlangsung secara terus menerus dan akan berhenti jika iterasi maksimum tercapai.

6. Ketika iterasi maksimum tercapai, maka daya output generator dengan biaya pembangkitan termurah akan ditampilkan.[9]

Parameter-parameter IABC yang ditujukan untuk menyelesaikan permasalahan DED terdiri dari

1. Sumber makanan (FoodNumber), Parameter yang menentukan banyaknya calon solusi daya dalam satu kali iterasi.

2. Jumlah koloni lebah (NP), Parameter yang menentukan banyaknya fase lebah pekerja dan fase lebah penonton

3. Batas (limit), Nilai batas eksploitasi pencarian nilai solusi daya baru dalam satu kali iterasi.

4. Siklus Maks (MaxCycle), Nilai iterasi untuk pencarian nilai minimal fungsi biaya. Proses iterasi memungkinkan mengulangi eksplorasi sebanyak nilai siklus maksimum-nya.

5. Modification rate (MR) dan Scaling Factor (SF), Parameter kontrol yang menentukan apakah nilai solusi daya acak perlu diperbarui atau tidak.

Tabel 1.

Korelasi IABC dengan DED

\begin{tabular}{cl}
\hline \hline Parameter & \multicolumn{1}{c}{ Keterangan } \\
\hline Lebah Pekerja & Pecarian solusi daya awal yang dicari \\
Lebah Penonton & $\begin{array}{l}\text { Pencarian solusi daya terbaik yang } \\
\text { diupdate }\end{array}$ \\
Lebah Pengintai & $\begin{array}{l}\text { Pencarian sumber solusi daya baru } \\
\text { Jumlah calon solusi daya dalam satu } \\
\text { kali iterasi. } \\
\text { Sumber makanan (Nektar) } \\
\text { Silai iterasi untuk pencarian nilai } \\
\text { minimal fungsi biaya }\end{array}$ \\
Modification Rate (MR) dan & Parameter kontrol pertubasi \\
Scaling Factor (SF) &
\end{tabular}

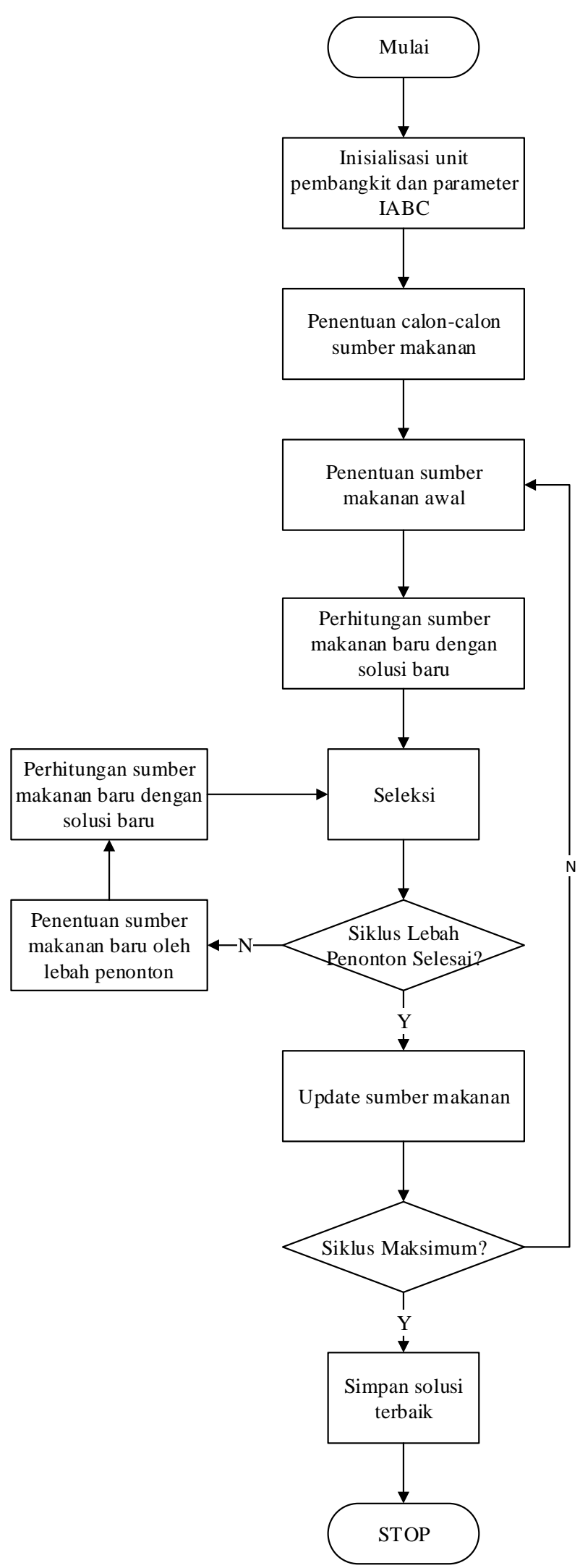

Gambar 2. Flowchart IABC 


\section{PENGUJIAN DAN ANALISA}

Pengujian optimasi sistem dilakukan sebanyak 3 (tiga) yaitu:

1. Dynamic Economic Dispatch dengan data sistem IEEE 6 unit generator tanpa mempertimbangkan prohibited operating zones.

2. Dynamic Economic Dispatch dengan data sistem IEEE 6 unit generator dengan mempertimbangkan prohibited operating zones.

3. Dynamic Economic Dispatch dengan data sistem IEEE 15 unit generator dengan mempertimbangkan prohibited operating zones.

Pemodelan sistem diolah dan disusun dengan software MATLAB. Pada algortima Improved Artificial Bee Colony, terdapat 7 macam parameter yang diatur yaitu :

Tabel 2.

Parameter IABC

\begin{tabular}{ccc}
\hline Parameter & Simbol & Nilai (IABC) \\
\hline Jumlah koloni lebah & NP & 500 \\
Jumlah sumber makanan & FoodNumber & 250 \\
Limit & Limit & 200 \\
Siklus maksimum & MaxCycle & 200 \\
Runtime & Runtime & 1 \\
Modification Rate & MR & 0.4 \\
Scaling Factor & SF & 1 \\
\hline \hline
\end{tabular}

\section{1) Sistem IEEE 6 Unit Generator}

\section{a) Data Sistem IEEE 6 Unit Generator}

Pada sistem IEEE 6 unit generator termalterdiri dari data fungsi biaya, data kapasitas limit generator, batasan ramp rate dan data permintaan daya beban 24 jam.

Tabel 3.

Data Fungsi Biaya dan Batasan Unit Pembangkit Sistem IEEE 6 Unit Generator

\begin{tabular}{cccccccc}
\hline \hline \multirow{2}{*}{ Unit } & \multicolumn{3}{c}{ Cost Function } & & & & \\
\cline { 2 - 4 } & \multicolumn{1}{c}{$\mathbf{a}$} & $\mathbf{b}$ & $\mathbf{c}$ & & $\mathbf{P}^{\max }$ & $\mathbf{U R}$ & DR \\
\hline 1 & 0.0070 & 7 & 240 & 100 & 500 & 80 & 120 \\
2 & 0.0095 & 10 & 200 & 50 & 200 & 50 & 90 \\
3 & 0.0090 & 8,5 & 220 & 80 & 300 & 65 & 100 \\
4 & 0.0090 & 11 & 200 & 50 & 150 & 50 & 90 \\
5 & 0.0080 & 10,5 & 220 & 50 & 200 & 50 & 90 \\
6 & 0.0075 & 12 & 190 & 50 & 120 & 50 & 90 \\
\hline \hline
\end{tabular}

Tabel 4.

Permintaan Daya Beban 24 Jam IEEE 6 Unit Generator

\begin{tabular}{cccccccc}
\hline \hline Jam & $\mathbf{P}_{\mathbf{i}}$ & $\mathbf{J a m}$ & $\mathbf{P}_{\mathbf{i}}$ & $\mathbf{J a m}$ & $\mathbf{P}_{\mathbf{i}}$ & $\mathbf{J a m}$ & $\mathbf{P}_{\mathbf{i}}$ \\
\hline 1 & 963 & 7 & 997 & 13 & 1263 & 19 & 1170 \\
2 & 949 & 8 & 1032 & 14 & 1276 & 20 & 1102 \\
3 & 942 & 9 & 1136 & 15 & 1262 & 21 & 1031 \\
4 & 937 & 10 & 1160 & 16 & 1233 & 22 & 992 \\
5 & 942 & 11 & 1212 & 17 & 1213 & 23 & 983 \\
6 & 971 & 12 & 1247 & 18 & 1263 & 24 & 967 \\
\hline \hline
\end{tabular}

Pengujian dilakukan dengan kondisi parameter algoritma IABC seperti pada tabel 2, dimana pengujian yang didapatkan cukup lama tetapi didapatkan hasil yang lebih baik. b) Hasil Pengujian

Tabel 5.

Biaya Total Sistem per 24 Jam

\begin{tabular}{crlccl}
\hline \hline Jam & P total & Biaya & Jam & P total & Biaya \\
\hline 1 & 963 & 11427,44 & 13 & 1201 & 14459,46 \\
2 & 949 & 11254,74 & 14 & 1263 & 15275,93 \\
3 & 942 & 11168,64 & 15 & 1276 & 15448,46 \\
4 & 937 & 11107,24 & 16 & 1262 & 15262,68 \\
5 & 942 & 11168,64 & 17 & 1233 & 14879,55 \\
6 & 971 & 11526,42 & 18 & 1213 & 14616,67 \\
7 & 997 & 11849,58 & 19 & 1170 & 14055,19 \\
8 & 1032 & 12288,20 & 20 & 1102 & 13177,63 \\
9 & 1136 & 13614,82 & 21 & 1031 & 12275,61 \\
10 & 1160 & 13925,34 & 22 & 992 & 11787,26 \\
11 & 1212 & 14603,55 & 23 & 983 & 11675,29 \\
12 & 1247 & 15064,22 & 24 & 967 & 11476,90 \\
\hline \hline
\end{tabular}

Total Biaya $=313389,5$

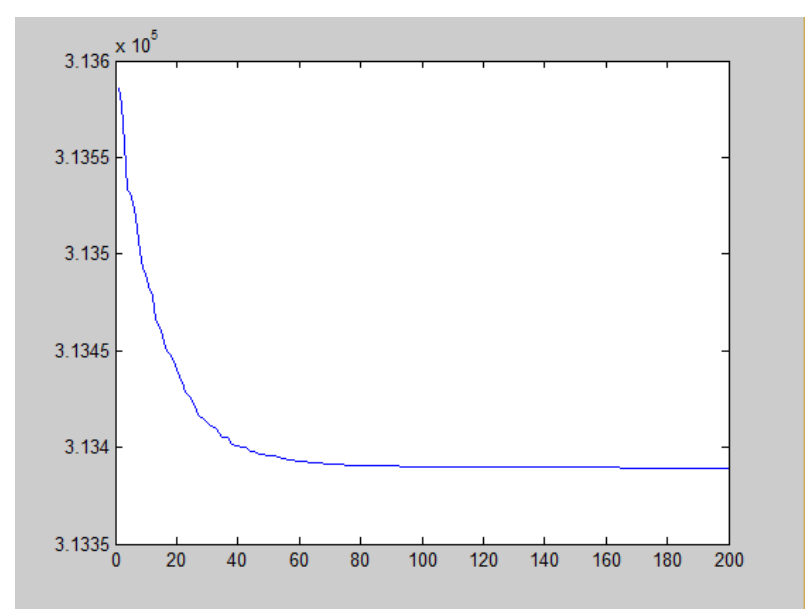

Gambar 3. Grafik Konvergensi IEEE 6 Unit Generator Tanpa POZ

Pada kasus ini, metode IABC dapat dikatakan bekerja dengan baik tetapi, perlu memodifikasi program IABC agar berjalan dengan baik tanpa melanggar batasan sehingga dapat digunakan pada studi kasus dengan permasalahan batasan POZ. Tabel 5 menunjukkan biaya pembangkitan total adalah \$313389.5/d. Biaya pembangkitan didapatkan melalui perhitungan fungsi objektif dynamic economic dispatch.

\section{2) Sistem IEEE 6 Unit Generator-POZ}

a) Data Sistem IEEE 6 Unit Generator-POZ

Tabel 6.

Data POZ Sistem IEEE 6 Unit Generator

\begin{tabular}{|c|c|}
\hline Unit & POZ (MW) \\
\hline 1 & {$\left[\begin{array}{lll}210 & 240]\end{array}\left[\begin{array}{lll}350 & 380\end{array}\right]\right.$} \\
\hline 2 & {$\left[\begin{array}{ll}90 & 110\end{array}\right]\left[\begin{array}{ll}140 & 160\end{array}\right]$} \\
\hline 3 & {$\left[\begin{array}{lll}150 & 170\end{array}\right]\left[\begin{array}{ll}210 & 240\end{array}\right]$} \\
\hline 4 & {$\left[\begin{array}{l}80 \\
80\end{array}\right]\left[\begin{array}{ll}110 & 120\end{array}\right]$} \\
\hline 5 & {$\left[\begin{array}{ll}90 & 110\end{array}\right]\left[\begin{array}{lll}140 & 150\end{array}\right]$} \\
\hline 6 & {$\left[\begin{array}{ll}75 & 85\end{array}\right] \quad\left[\begin{array}{lll}100 & 105\end{array}\right]$} \\
\hline
\end{tabular}

Parameter algoritma IABC ditunjukkan pada tabel 2 . Parameter karakteristik pembangkit disamakan seperti studi 
kasus 1 pada Tabel 3 dan permintaan daya tiap waktu selama 24 jam seperti pada Tabel 4.

b) Hasil Pengujian

Tabel 7.

Biaya Total Sistem per 24 Jam

\begin{tabular}{cccccc}
\hline \hline Jam & P total & Biaya & Jam & P total & Biaya \\
\hline 5 & 942 & 11169 & 17 & 1233 & 14880 \\
6 & 971 & 11527 & 18 & 1213 & 14617 \\
7 & 997 & 11851 & 19 & 1170 & 14055 \\
8 & 1032 & 12290 & 20 & 1102 & 13179 \\
9 & 1136 & 13616 & 21 & 1031 & 12278 \\
10 & 1160 & 13926 & 22 & 992 & 11788 \\
11 & 1212 & 14604 & 23 & 983 & 11676 \\
12 & 1247 & 15064 & 24 & 967 & 11477 \\
\hline \hline
\end{tabular}

Total Biaya $=313404$

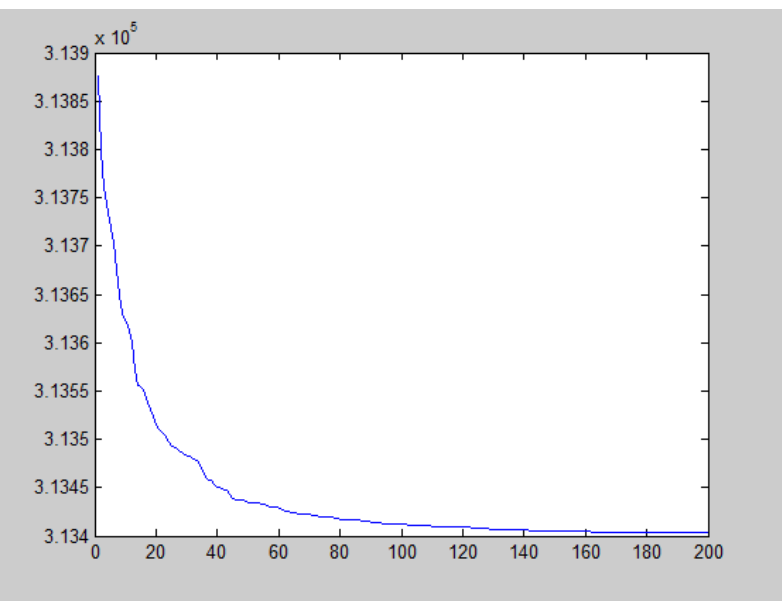

Gambar 4. Grafik Konvergensi IEEE 6 Unit Generator Dengan POZ

Pada kasus ini, tidak ada unit pembangkit yang pembangkitannya berada pada zona POZ. Hasil pengujian studi kasus sistem IEEE 6 unit generator dengan POZ menghasilkan keluaran yang baik. Metode IABC dianggap lebih baik dengan harga termurah yaitu, \$313404/h dibanding metode pembanding seperti, Genetic Algorithm (GA), Improved Bee Algorithm (IBA), dan Particle Swarm Optimization (PSO) pada tabel 8. Biaya pembangkitan didapatkan melalui perhitungan fungsi objektif dynamic economic dispatch.

Tabel 8.

Komparasi Metode IEEE 6 Unit Generator Dengan POZ [3]

\begin{tabular}{cc} 
Metode & Total Biaya (\$) \\
\hline GA & 314933 \\
IBA & 313993 \\
PSO & 314134 \\
IABC & 313404 \\
\hline \hline
\end{tabular}

\section{3) Data Sistem IEEE 15 Unit Generator-POZ}

a) Data Sistem IEEE 15 Unit Generator-POZ

Pada sistem IEEE 6 unit generator termalterdiri dari data fungsi biaya, data kapasitas limit generator, batasan ramp rate dan data permintaan daya beban 24 jam. Parameter algoritma IABC ditunjukkan pada tabel 2.
Tabel 9.

Permintaan Daya Beban 24 Jam IEEE 15 Unit Generator

\begin{tabular}{llcccc}
\hline \hline Jam & $\begin{array}{l}\text { Beban } \\
\text { (MW) }\end{array}$ & Jam & $\begin{array}{l}\text { Beban } \\
\text { (MW) }\end{array}$ & Jam & $\begin{array}{l}\text { Beban } \\
\text { (MW) }\end{array}$ \\
\hline 1 & 2255,51 & 9 & 2678,78 & 17 & 2942,92 \\
2 & 2234,21 & 10 & 2759,15 & 18 & 2838,31 \\
3 & 2245,35 & 11 & 2816,76 & 19 & 2679,33 \\
4 & 2255,51 & 12 & 2818,89 & 20 & 2610,13 \\
5 & 2312,91 & 13 & 2813,57 & 21 & 2455,29 \\
6 & 2336,92 & 14 & 2866,57 & 22 & 2332,85 \\
7 & 2352,16 & 15 & 2997,24 & 23 & 2280,89 \\
8 & 2466,50 & 16 & 2994,14 & 24 & 2273,77 \\
\hline \hline
\end{tabular}

Tabel 10

Data POZ Sistem IEEE 15 Generator

\begin{tabular}{|c|c|}
\hline Unit & POZ (MW) \\
\hline 2 & [185 225] [ [305 335] [420 450] \\
\hline 5 & {$\left[\begin{array}{ll}90 & 110\end{array}\right]\left[\begin{array}{lll}140 & 150\end{array}\right]\left[\begin{array}{lll}390 & 420\end{array}\right]$} \\
\hline 6 & {$\left[\begin{array}{ll}75 & 85\end{array}\right]\left[\begin{array}{lll}100 & 105\end{array}\right]\left[\begin{array}{lll}430 & 455\end{array}\right]$} \\
\hline 12 & {$[3040]\left[\begin{array}{lll}55 & 65\end{array}\right]$} \\
\hline
\end{tabular}

b) Hasil Pengujian

Tabel 11

Biaya Total per Jam IEEE 15 Unit Generator

\begin{tabular}{cccccc}
\hline \hline Jam & P total & Biaya & Jam & P total & Biaya \\
\hline 1 & 2255,51 & 28360,98 & 13 & 2813,57 & 34232,82 \\
2 & 2234,21 & 28140,52 & 14 & 2866,57 & 34797,12 \\
3 & 3245,35 & 28255,66 & 15 & 2997,24 & 36287,52 \\
4 & 2255,51 & 28360,60 & 16 & 2994,14 & 36234,70 \\
5 & 2312,91 & 29013,17 & 17 & 2942,92 & 35677,69 \\
6 & 2336,92 & 29202,54 & 18 & 2838,31 & 34529,09 \\
7 & 2352,16 & 29360,66 & 19 & 2679,33 & 32809,55 \\
8 & 2466,50 & 30549,26 & 20 & 2610,13 & 32069,51 \\
9 & 2678,78 & 32883,81 & 21 & 2455,29 & 30445,90 \\
10 & 2759,15 & 33772,79 & 22 & 2332,85 & 29160,56 \\
11 & 2816,76 & 34334,51 & 23 & 2280,89 & 28624,43 \\
12 & 2818,89 & 34309,21 & 24 & 2273,77 & 28549,29 \\
\hline & & Total Biaya $=759959,8$ & \\
\hline \hline
\end{tabular}

Pada tabel 11 didapatkan hasil pembangkitan biaya total sebesar \$ 759959.8/d. Grafik optimasi algoritma IABC menunjukkan biaya pembangkitan yang turun seiring dengan banyak siklus iterasinya.

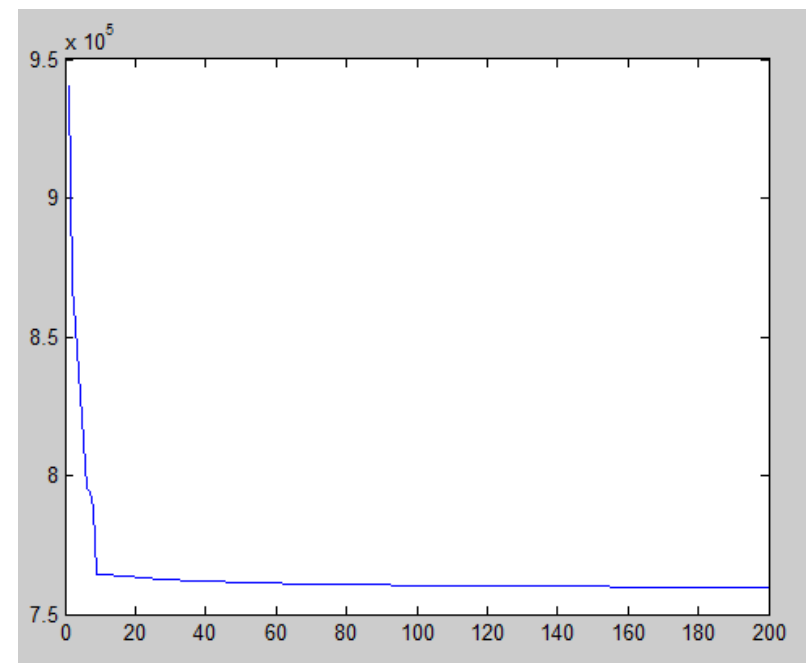

Gambar 5. Grafik Konvergensi IEEE 15 Unit Generator 


\section{KESIMPULAN}

Berdasarkan hasil yang didapatkan dari simulasi dan analisis pada penelitian ini, maka dapat diambil beberapa kesimpulan sebagai berikut :

1. Pengujian dynamic economic dispatch tanpa mempertimbangkan POZ pada sistem IEEE 6 unit generator menghasilkan total biaya sebesar 313389.5 \$/d, dibandingkan dynamic economic dispatch dengan mempertimbangkan POZ pada sistem IEEE 6 unit generator $313403.8 \$ / \mathrm{d}$.

2. Pengujian dynamic economic dispatch dengan mempertimbangkan POZ pada sistem IEEE 15 unit generator menghasilkan total biaya sebesar 760224.3 $\$ /$ d.

3. Dibandingkan dengan algoritma pembanding lain pada sistem serupa, algoritma Artificial Bee Colony mampu memberikan waktu komputasi yang lebih cepat dan hasil yang cukup akurat.

4. Semakin banyak unit pembangkit yang dimasukkan dalam perhitungan, maka dibutuhkan besar koloni dan siklus yang lebih banyak untuk mendapatkan hasil nilai optimasi yang optimal (konvergen).

5. Efek Prohibited Operating Zones pada pengujian dynamic economic dispatch dibawah $1 \%$, tetapi harus dipertimbangkan dalam perhitungan optimasi dynamic economic dispatch demi kontinuitas kerja unit generator

\section{DAFTAR PUSTAKA}

[1] Gamayanti N., Alkaff, Karim A., "Optimisasi Dynamic Economic Dispatch Menggunakan Algoritma Artificial Bee Colony,” JAVA J. Electr. Electron. Eng., vol. 13, Apr 2015.

[2] Wood, A. J., Wollenberg, B. F., "Power Generation Operation And Control," John Wiley \& Sons Inc., 2001.

[3] Sharma M.K., Phonrattanasak P., Leeprechanon N., "Improved bees algorithm for dynamic economic dispatch considering prohibited operating zones," IEEE, Jan 2016.

[4] Ibrahim R. S., S. W. Rony, Musthofa A., "Economic Load Dispatch Unit Pembangkit Termal Mempertimbangkan Penambahan Pembangkit Tenaga Angin dengan Menggunakan Firefly Algorithm”, Jurnal Teknik ITS, ITS, 2017.

[5] Özyön S., Durmuş B., "The Application of Artificial Bee Colony Algorithm for the Economic Power Dispatch with Prohibited Operating Zone," IEEE, 2012.

[6] Nagur P. N., R. Shubham, Jadhav H.T., "Modified Artificial Bee Colony Algorithm for Non-Convex Economic Dispatch Problems," IEEE, 2012

[7] Karaboga D., Akay B., “A modified Artificial Bee Colony (ABC) algorithm for constrained optimization problems," Elsevier Journal, Dec 2010.

[8] A. P. Dio, P. Ontoseno, and A. Ni Ketut, "Economic and Emission Dispatch Pada Sistem Transmisi Jawa Bali 500 kV Berdasarakan RUPTL 2015 - 2024 Menggunakan Modified Artificial Bee Colony Algorithm," ITS, 2016.

[9] Akay B., Karaboga D., "A modified Artificial Bee Colony algorithm for real-parameter optimization”, Elsevier, 2010. 